\title{
Isolation of lactic acid bacteria bound to the porcine intestinal mucosa and an analysis of their moonlighting adhesins
}

\author{
Hideki KINOSHITA ${ }^{1 *}$, Satoko OHUCHI ${ }^{2}$, Kensuke ARAKAWA ${ }^{3}$, Masamichi WATANABE ${ }^{4}$, \\ Haruki KITAZAWA ${ }^{5}$ and Tadao SAITO ${ }^{5}$ \\ ${ }^{1}$ Laboratory of Food Biochemistry, Department of Bioscience, School of Agriculture, Tokai University, Kawayo, Minami Aso-mura, \\ Aso-gun, Kumamoto, Japan \\ ${ }^{2}$ Department of Food Management, School of Food, Agricultural and Environmental Sciences, Miyagi University, 2-2-1 Hatatate, \\ Taihaku-ku, Sendai, Miyagi, Japan \\ ${ }^{3}$ Graduate School of Environmental and Life Science, Okayama University, 1-1-1 Tsushima-naka, Okayama, Japan \\ ${ }^{4}$ Research Faculty of Agriculture, Hokkaido University, Kita 9, Nishi 9, Kita-ku, Sapporo, Hokkaido 060-8589, Japan \\ ${ }^{5}$ Laboratory of Animal Products Chemistry, Graduate School of Agricultural Science, Tohoku University, 1-1 Tsutsumidori- \\ Amamiyamachi, Aoba-ku, Sendai, Miyagi, Japan
}

Received June 15, 2016; Accepted July 10, 2016; Published online in J-STAGE August 2, 2016

The adhesion of lactic acid bacteria (LAB) to the intestinal mucosa is one of the criteria in selecting for probiotics. Eighteen LAB were isolated from porcine intestinal mucin (PIM): ten strains of Lactobacillus, six strains of Weissella, and two strains of Streptococcus. Using sodium dodecyl sulfate polyacrylamide gel electrophoresis (SDS-PAGE) for phosphate-buffered saline (PBS) extracts from the LAB, many bands were detected in half of the samples, while a few and/or no clear bands were detected in the other half. All six of the selected LAB showed adhesion to PIM. L. johnsonii MYU 214 and MYU 221 showed adhesion at more than 10\%. W. viridescens MYU 208, L. reuteri MYU 213, L. mucosae MYU 225, and $L$. agilis MYU 227 showed medium levels of adhesion at 5.9-8.3\%. In a comprehensive analysis for the adhesins in the PBS extracts using a receptor overlay analysis, many moonlighting proteins were detected and identified as candidates for adhesins: GroEL, enolase, and elongation factor Tu in MYU 208; peptidase C1, enolase, formyl-CoA transferase, phosphoglyceromutase, triosephosphate isomerase, and phosphofructokinase in MYU 221; and DnaK, enolase, and phosphoglycerate kinase in MYU 227. These proteins in the PBS extracts, which included such things as molecular chaperones and glycolytic enzymes, may play important roles as adhesins.

Key words: adhesion, adhesin, moonlighting protein, lactic acid bacteria, probiotics, porcine intestinal mucin

\section{INTRODUCTION}

Lactic acid bacteria (LAB) are commonly used as probiotics. LAB have many beneficial effects; for example, they can be used to manage lactose intolerance [1], lower cholesterol [2], improve immune function [3], prevent colon cancer [4], and inhibit the adherence of various pathogens [5-7]. LAB are often isolated from the alimentary canal and feces of humans and animals

\footnotetext{
*Corresponding author. Hideki Kinoshita, Laboratory of Food Biochemistry, Department of Bioscience, School of Agriculture, Tokai University, Kawayo, Minami Aso-mura, Aso-gun, Kumamoto, Japan. Phone: +81-96-386-2690; E-mail: kinoshita@tokai. ac.jp

(C) 2016 BMFH Press

This is an open-access article distributed under the terms of the Creative Commons Attribution Non-Commercial No Derivatives (bync-nd) License $<$ http://creativecommons.org/licenses/by-nc-nd/4.0/>.
}

[8-11] and are used in fermented foods as probiotics. One potentially important property of these organisms is their ability to interact with the mucosa or mucus in the intestinal tract, which may promote retention and host-bacteria communication. The ability of a strain to adhere to the intestinal mucosa is one of the criteria used to select probiotic microorganisms. Lactobacilli contain many types of adhesins, e.g., SlpA [12, 13], CdpA [14], Mub [15], FbpA [16], CbsA [17], Msa [18], CnBP (ABC transporter) [19, 20], MapA [21], LspA [22], bacterial cell surface carbohydrate [23], and lipoteichoic acid [24].

Recently, the idea of one gene-one protein-one function has been challenged by evidence that many proteins have multiple functions. For example, many cytosolic proteins are expressed on the bacterial cell surface and have other functions in many LAB strains. These proteins are referred to as "moonlighting proteins," which are defined as single proteins that have multiple functions. Recently, 
many moonlighting proteins have been identified; for example, glyceraldehyde-3-phosphate dehydrogenase $(\mathrm{GAPDH})$, enolase, glutamine synthetase (GS), elongation factor Tu (EF-Tu), GroEL, and DnaK exist on bacterial cell surfaces in probiotic bacteria [25-31]. Previously, we reported that GAPDH expressed on the bacterial cell surfaces of Lactobacillus plantarum LA 318 isolated from human intestinal tissue (transverse colon) [32] binds to human colonic mucin [28] and to the Aand B-type antigens of the ABO blood type group [33]. GAPDH is universally expressed on the cell surfaces of many lactobacilli [34]. According to Antikainen et al. [30], GAPDH and enolase bind to lipoteichoic acid on the bacterial cell surface by ionic bonds. We also found that GAPDH can be easily extracted using phosphate-buffered saline (PBS, pH 7.4) [28]. However, the identities and functions of moonlighting proteins, such as adhesins, are unclear. Here, we examined moonlighting proteins that can be extracted with PBS to comprehensively analyze adhesins in LAB.

\section{MATERIALS AND METHODS}

\section{Isolation of LAB from porcine intestinal mucin and culture conditions}

MRS agar was prepared by adding $1.5 \%$ agar (Wako Pure Chemical Industries, Osaka, Japan) to MRS broth (Difco Laboratories, Detroit, MI, USA). Modified LBS (mLBS) agar was prepared by adding $0.8 \%(w / v) ~ L a b-$ Lemco Powder (Oxoid, Basingstoke, Hampshire, UK), $0.1 \mathrm{~mol} / \mathrm{l}$ sodium acetate, and $3.7 \%(\mathrm{v} / \mathrm{v})$ acetic acid to LBS agar (Becton Dickinson and Company, Sparks, MD, USA).

The surface mucus layer was gently scraped from porcine intestinal samples using a glass slide and incubated on MRS agar, mLBS agar, or BL agar (Nissui, Tokyo, Japan) in an anaerobic jar for $48 \mathrm{hr}$ at $37^{\circ} \mathrm{C}$. Colonies differing in color, form, and size were selected from each plate and propagated with MRS broth (Difco Laboratories) at $37^{\circ} \mathrm{C}$; for subsequent experiments, they were stored at $-80^{\circ} \mathrm{C}$.

Bacterial strains were propagated twice at $37^{\circ} \mathrm{C}$ for $24 \mathrm{hr}$ in MRS broth with $2 \%(\mathrm{v} / \mathrm{v})$ inoculum before the experiments.

\section{Identification of isolated bacteria}

The isolated bacteria were identified using Gram staining, morphological observations, catalase tests, carbohydrate fermentation tests with API $50 \mathrm{CH}$ (bioMérieux, St. Louis, MO, USA), and a homology search using $16 \mathrm{~S}$ rDNA sequences. Amplification of the total $16 \mathrm{~S}$
rDNA was performed using the following pair of universal primers: 27f (5'-AGAGTTTGATCCTGGCTCAG-3') and $1525 \mathrm{r}$ (5'-AGAAAGGAGGTGATCCAGCC-3') [35]. The homology search was performed using BLAST against the DDBJ, EMBL, and GenBank databases.

\section{Isolation and purification of PIM}

Porcine intestinal mucin (PIM) in the adherent mucosa was prepared from fresh porcine intestinal tissues by scraping with slide glass. Isolation and purification of PIM were performed as described previously [32].

Lipids from crude PIM were removed using three sequential extractions with chloroform:methanol (2:1, $\mathrm{v} / \mathrm{v}$ ) and diethyl ether. The lipid-free PIM was dissolved in $4 \mathrm{~mol} / \mathrm{l}$ guanidine hydrochloride $(\mathrm{GHCl})$ solution and fractionated by gel filtration chromatography using a Toyopearl HW-65F Column $(100 \mathrm{~cm} \times 2.5 \mathrm{~cm}$, Bio-Rad Laboratories, Hercules, CA, USA). Protein absorbance was monitored at $280 \mathrm{~nm}$, and neutral sugars were detected at $490 \mathrm{~nm}$ using the phenol- $\mathrm{H}_{2} \mathrm{SO}_{4}$ method [36]. The fractions containing the highest sugar contents were dialyzed against distilled water at $4{ }^{\circ} \mathrm{C}$ for 2 days and then lyophilized.

\section{Carboxyfluorescein diacetate labeling of $L A B$}

$\mathrm{LAB}$ were cultured at $37^{\circ} \mathrm{C}$ for $18 \mathrm{hr}$ in MRS broth and centrifuged (3,000 rpm, $10 \mathrm{~min}$, room temperature). The pellets were washed with sterilized distilled water three times $\left(8,000 \mathrm{rpm}, 5 \mathrm{~min}, 4^{\circ} \mathrm{C}\right)$. The pellets were resuspended in $1 \mathrm{ml}$ of sterilized distilled water, and $100 \mu \mathrm{l}$ of $1 \mathrm{mmol} / \mathrm{l}$ carboxyfluorescein diacetate (CFDA) in PBS was added. After incubation for $30 \mathrm{~min}$ at $37^{\circ} \mathrm{C}$ in the dark, the CFDA-labeled microbial cells were washed with sterilized distilled water three times $(8,000 \mathrm{rpm}$, 5 min, $4^{\circ} \mathrm{C}$ ).

\section{Test of adhesion of LAB to PIM}

Reacti-Bind $^{\mathrm{TM}}$ Amine-binding Maleic Anhydride Activated Plates (Pierce, Rockford, IL, USA) that allow attachment of amine-containing proteins to microplate wells were used for microtiter plate binding assay. Purified unlabeled PIM $(0.3 \mathrm{mg} / \mathrm{ml})$ was dissolved in PBS $(100 \mu \mathrm{l})$, added to each well, and incubated overnight at $4^{\circ} \mathrm{C}$. After decantation, each well was blocked with $5 \%$ skim milk in PBS for $5 \mathrm{hr}$ at $4^{\circ} \mathrm{C}$; the plates were then used for the binding assay. After immobilization of PIM, each well was washed three times with $250 \mu$ of PBS with $0.05 \%$ Tween 20 (PBS-T). Then, $100 \mu \mathrm{l}$ of $1 \times 10^{8}$ cells $/ \mathrm{ml}$ CFDA-labeled LAB cells in distilled water were added to the wells. Three parallel wells were used for each experiment. The microbial cells were allowed to 
adhere for $1 \mathrm{hr}$ at $37^{\circ} \mathrm{C}$, and the wells were washed three times with $250 \mu \mathrm{l}$ of PBS to remove non-adherent cells. The cells bound to PIM were released and lysed using $1 \%(\mathrm{w} / \mathrm{v})$ sodium dodecyl sulfate (SDS) $/ 0.1 \mathrm{~mol} / \mathrm{l} \mathrm{NaOH}$ solution and incubated for $1 \mathrm{hr}$ at $60^{\circ} \mathrm{C}$. After incubation, the fluorescence intensity (excitation, $485 \mathrm{~nm}$; emission, $538 \mathrm{~nm}$ ) of the lytic solution was measured using a Fluoroskan Ascent plate reader (Thermo Fisher Scientific, Inc., Waltham, MA, USA). PBS was used as the control in place of PIM. The adhesion value was defined as the value of the mucin-LAB immobilized on the plate reduced by the control value. The results are shown as adhesion rates $(\%)$ and were calculated as follows:

Adhesion rate $(\%)=($ fluorescence intensity of adherent LAB) - (fluorescence intensity of PBS control)/(initial fluorescence intensity of LAB) $\times 100$.

Lactobacillus plantarum LA 318 was used as a positive control; it shows high adhesion to the human colonic mucin and blood type antigens (A and B antigens) [28, $32,33]$.

\section{Sample preparation for SDS-PAGE and the receptor overlay analysis}

Eighteen strains isolated from PIM were cultured at $37^{\circ} \mathrm{C}$ for $18 \mathrm{hr}$ in MRS broth (Difco Laboratories) using a $2 \%(\mathrm{v} / \mathrm{v})$ inoculum. Bacterial cells after culture were washed three times with sterile distilled water. After washing, the pellets were suspended in PBS and incubated at $4^{\circ} \mathrm{C}$ for $30 \mathrm{~min}$. After centrifugation $(8,000 \mathrm{rpm}$, $5 \mathrm{~min}, 4^{\circ} \mathrm{C}$ ), the supernatant was dialyzed, lyophilized, and used as the PBS extract sample for sodium dodecyl sulfate polyacrylamide gel electrophoresis (SDS-PAGE) and the receptor overlay (RO) analysis.

\section{SDS-PAGE}

Cell surface proteins prepared from the $18 \mathrm{LAB}$ were analyzed using SDS-PAGE according to the methods of Laemmli [37]. PBS extract samples were denatured in SDS buffer (60 mmol/1 Tris, 25\% glycerol, 2\% SDS, $2 \% \beta$-mercaptoethanol, and $0.1 \%$ bromophenol blue; $\mathrm{pH}$ 6.8) at $1 \mathrm{mg} / \mathrm{ml}$ and heated at $95^{\circ} \mathrm{C}$ for $10 \mathrm{~min}$. Electrophoresis was performed using polyacrylamide gels with a discontinuous buffer system, a 4.5\% stacking gel, and a $12.5 \%$ separation gel $(10 \times 12 \mathrm{~cm})$. Electrophoresis was performed using a Mini-PROTEAN III Dual Slab Cell (Bio-Rad) at a constant voltage of 125 $\mathrm{V}$ in running buffer containing $25 \mathrm{mmol} / 1$ Tris, $0.2 \mathrm{~mol} / \mathrm{l}$ glycine, and $0.1 \%$ SDS. Protein bands were visualized by staining the gels with Coomassie Brilliant Blue (CBB) (Rapid CBB; Kanto Chemical Co., Inc., Tokyo, Japan). Molecular weight markers from 14 to 97 kDa (AE-1440
EzStandard, Atto Co., Ltd., Tokyo, Japan) were used.

\section{Biotinylation of PIM and BSA}

The purified PIM or bovine serum albumin (BSA; $1.0 \mathrm{mg}$ ) was diluted with $1 \mathrm{~mL}$ of $50 \mathrm{mmol} / 1$ borate$\mathrm{NaOH}$ buffer ( $\mathrm{pH} 9.0)$ and centrifuged $(8,000 \mathrm{rpm}$, $\left.5 \mathrm{~min}, 4^{\circ} \mathrm{C}\right)$. The supernatant $(200 \mu \mathrm{l})$ was supplemented with $2 \mu \mathrm{l}$ of $N, N$-dimethylformamide (DMF, Thermo Fisher Scientific) containing EZ-Link Sulfo-NHS-LCBiotin (Thermo Fisher Scientific) $(25 \mu \mathrm{g} / \mathrm{ml})$ and was reacted for $2 \mathrm{hr}$ at $4^{\circ} \mathrm{C}$. After biotinylation, each sample (100 $\mu \mathrm{l})$ was dialyzed against distilled water using SlideA-lyzer MINI Dialysis Units (Thermo Fisher Scientific) in the dark and was used as biotinylated PIM or BSA. The biotinylated BSA was used as a control protein.

\section{Detection of adhesins using an $R O$ analysis}

Adhesins were detected using an RO analysis according to the methods of Ilver et al. [38], with some modifications.

The PBS extract sample was diluted with SDS sample buffer for electrophoresis (2ME-, Wako Pure Chemical Industries) $(1 \mathrm{mg} / \mathrm{ml})$ and was applied to SDS-PAGE. After electrophoresis, proteins were electrophoretically transferred to a polyvinylidene difluoride (PVDF) membrane (Applied Biosystems, Tokyo, Japan) using a semi-dry blotting apparatus (Semi-Phor, Hoefer Scientific, San Francisco, CA, USA). The membrane was blocked with TBS-T (Tris-buffered saline with Tween-20, pH 7.5) containing 5\% skim milk for $30 \mathrm{~min}$. After washing with TBS-T, the membrane was soaked in TBS-T containing the biotinylated PIM (final concentration $1.0 \mathrm{~g} / \mathrm{ml}$ ) overnight. After washing with TBS-T, ExtrAvidin Alkaline Phosphatase Conjugate (Sigma-Aldrich) was added, followed by incubation for $30 \mathrm{~min}$. After washing with TBS-T, ECF Substrate for Western Blotting (GE Healthcare, Tokyo, Japan) was added, and visualization was performed using an LAS-3000 luminescent image analyzer (Fujifilm, Tokyo, Japan) (excitation, $440 \mathrm{~nm}$; emission, $560 \mathrm{~nm}$ ).

Biotinylated molecular weight markers (SigmaAldrich) were used for SDS-PAGE. Biotinylated BSA was used as a control protein instead of biotinylated PIM to identify mucin-binding adhesion proteins. TBS-T was used as a negative control to exclude nonspecific binding.

\section{$N$-terminal sequence analysis}

After the SDS-PAGE analysis, proteins from the PBS extract were electrophoretically transferred to a PVDF membrane. Then, the membrane was visualized using Amido Black 10B (Wako Pure Chemical Industries) in 7\% 
Table 1. Identification of isolated bacteria from porcine intestinal mucus

\begin{tabular}{cclcc}
\hline Strain no. & Culture agar & \multicolumn{1}{c}{ Species } & Homology & Accession No. \\
\hline MYU 135 & mLBS & Lactobacillus ruminis & $100 \%$ & LC163924 \\
MYU 136 & mLBS & Lactobacillus amylovorus & $100 \%$ & LC163925 \\
MYU 200 & MRS & Weissella viridescens & $100 \%$ & LC163926 \\
MYU 203 & MRS & Weissella viridescens & $99 \%$ & LC163927 \\
MYU 204 & MRS & Weissella viridescens & $100 \%$ & LC163928 \\
MYU 205 & MRS & Weissella viridescens & $99 \%$ & LC163929 \\
MYU 207 & MRS & Weissella viridescens & $100 \%$ & LC163930 \\
MYU 208 & MRS & Weissella viridescens & $100 \%$ & LC163931 \\
MYU 212 & mLBS & Streptococcus alactolyticus & $100 \%$ & LC163932 \\
MYU 213 & mLBS & Lactobacillus reuteri & $99 \%$ & LC163933 \\
MYU 214 & mLBS & Lactobacillus johnsonii & $100 \%$ & LC163934 \\
MYU 215 & mLBS & Lactobacillus reuteri & $99 \%$ & LC163935 \\
MYU 217 & mLBS & Streptococcus alactolyticus & $99 \%$ & LC163936 \\
MYU 220 & BL & Lactobacillus reuteri & $99 \%$ & LC163937 \\
MYU 221 & BL & Lactobacillus johnsonii & $99 \%$ & LC163938 \\
MYU 224 & BL & Lactobacillus mucosae & $99 \%$ & LC163939 \\
MYU 225 & BL & Lactobacillus mucosae & $99 \%$ & LC163940 \\
MYU 227 & BL & Lactobacillus agilis & $100 \%$ & LC163941 \\
\hline
\end{tabular}

acetic acid solution. The protein bands that corresponded to mucin-binding proteins in the $\mathrm{RO}$ analysis were cut from the membrane and washed three times with $10 \%$ ethanol to remove glycine from the running buffer. $\mathrm{N}$-terminal amino acid sequencing was performed using Edman degradation [39]. A homology search was performed using BLAST against the DDBJ, EMBL, and GenBank databases. The molecular weight of a sample protein showing high homology to the N-terminal sequences of a sample was deduced using the Compute $\mathrm{pI} / \mathrm{Mw}$ tool (http://web.expasy.org/compute_pi/).

\section{Statistical analyses}

Adhesion tests were performed in triplicate, and results are reported as means $\pm \mathrm{SD}$. Statistical analyses were performed using Dunnett's test for the adhesion test after performing Kolmogorov-Smirnov's test for normality and Levene's test for equal variances.

\section{RESULTS}

\section{Isolation and identification of LAB from PIM}

Table 1 shows the isolated LAB species. Eighteen LAB were isolated from PIM, including ten strains of Lactobacillus, six strains of Weissella, and two strains of Streptococcus. With MRS agar and BL agar, Caulobacter sp., Staphylococcus sp., and Enterobacteriaceae (Klebsiella sp., Escherichia sp., or Shigella sp.) were detected. Only LAB (Streptococcus and Lactobacillus) were detected using mLBS agar.

\section{SDS-PAGE of the PBS extract}

Figure 1 shows the banding patterns for the SDSPAGE analysis using PBS extracts from the LAB. Various protein banding patterns were observed in each sample. Some common bands were detected at ca. 40-60 kDa. Clear protein bands were detected in PBS extracts from MYU 200, MYU 204, MYU 207, MYU 208, MYU 213, MYU 214, MYU 221, MYU 225, and MYU 227, while a few and/or no clear bands were detected in MYU 135, MYU 136, MYU 203, MYU 205, MYU 212, MYU 215, MYU 217, MYU 220, and MYU 224. Strains showing clear bands were selected for further investigation. However, MYU 200, MYU 204, and MYU 207 were excluded from subsequent analyses because they showed similar banding patterns to that of MYU 208.

\section{Test of adhesion of LAB to PIM}

Supplemental Figure 1 shows the gel filtration chromatograph for PIM. Fractions no. 47-61, which contained high protein and sugar contents, were collected and used as a purified PIM in the adhesion test and the $\mathrm{RO}$ analysis.

Figure 2 shows the rate of adhesion of each selected LAB strain to purified PIM. All strains showed adhesion to purified PIM, and the adhesion rates differed significantly among strains $(\mathrm{p}<0.01)$. L. plantarum LA318, a positive control, showed high adhesion at 19.0 $\pm 3.7 \%$. No significant differences were detected between the positive control and MYU $214(16.3 \pm 3.8 \%)$ and MYU $221(11.3 \pm 4.2 \%)$, whereas the adhesion rates of 

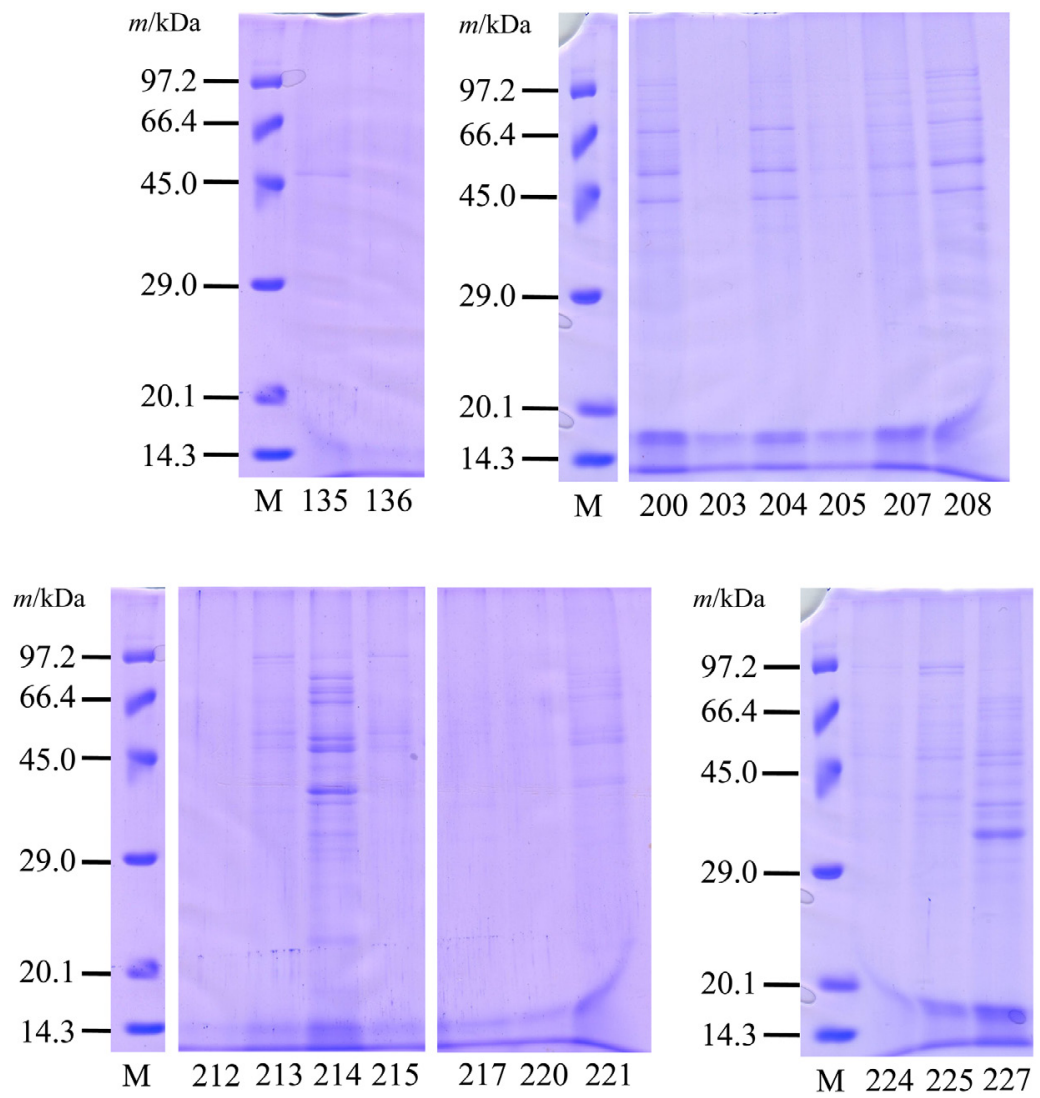

Fig. 1. SDS-PAGE of phosphate-buffered saline (PBS)-extracted proteins from lactic acid bacteria (LAB).

Bacterial cells were washed three times with sterile distilled water. The pellets were suspended in PBS and incubated at $4{ }^{\circ} \mathrm{C}$ for 30 min. After centrifugation, the supernatant was dialyzed and lyophilized. SDS-PAGE was performed using a $12.5 \%$ separation gel at a constant voltage of $125 \mathrm{~V}$. Protein bands were visualized using CBB staining. M: molecular weight marker. MYU strain numbers: 135-227.

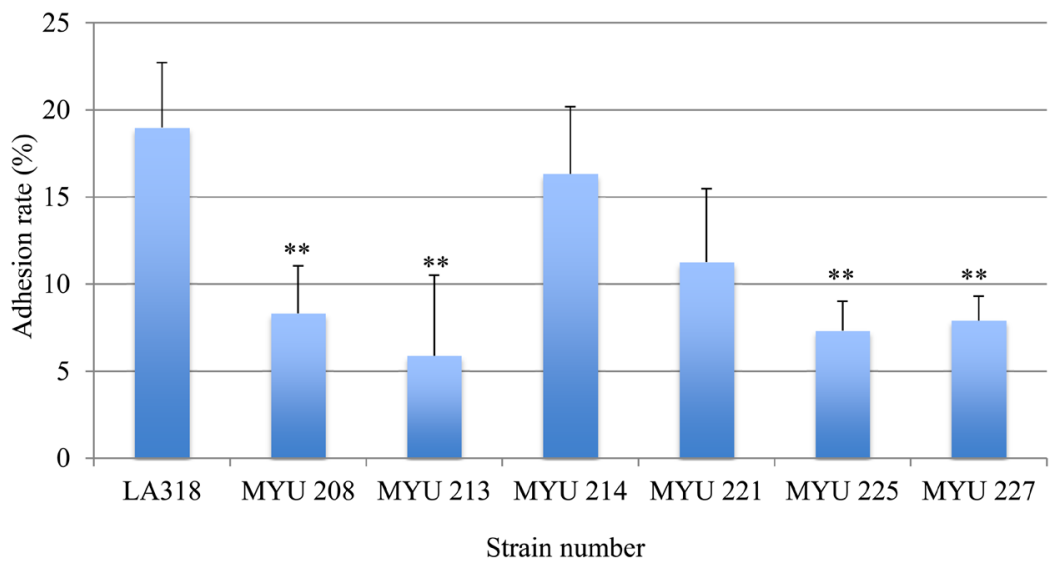

Fig. 2. Test of adhesion of selected LAB to porcine intestinal mucin (PIM).

Purified unlabeled PIM in PBS was added to each well and incubated overnight at $4^{\circ} \mathrm{C}$. After blocking and washing, $100 \mu \mathrm{L}$ of $1 \times 10^{8}$ cells $/ \mathrm{ml}$ CFDA-labeled LAB cells in distilled water was added to the wells. The microbial cells were allowed to adhere for $1 \mathrm{hr}$ at $37^{\circ} \mathrm{C}$, and the wells were washed three times with PBS to remove non-adherent cells. The cells bound to PIM were released and lysed using $1 \% \mathrm{SDS} / 0.1 \mathrm{M} \mathrm{NaOH}$ solution and incubated for $1 \mathrm{hr}$ at $60^{\circ} \mathrm{C}$. After incubation, the fluorescence intensity (excitation, $485 \mathrm{~nm}$; emission, $538 \mathrm{~nm}$ ) of the lytic solution was measured. PBS was used as the control in place of PIM. The adhesion value was defined as the value of the mucin-LAB immobilized on the plate reduced by the control value. The results are shown as adhesion rates (\%). L. plantarum LA 318 was used as a positive control.

** Significantly different compared with the control strain (LA 318) $(\mathrm{p}<0.01)$. 
A

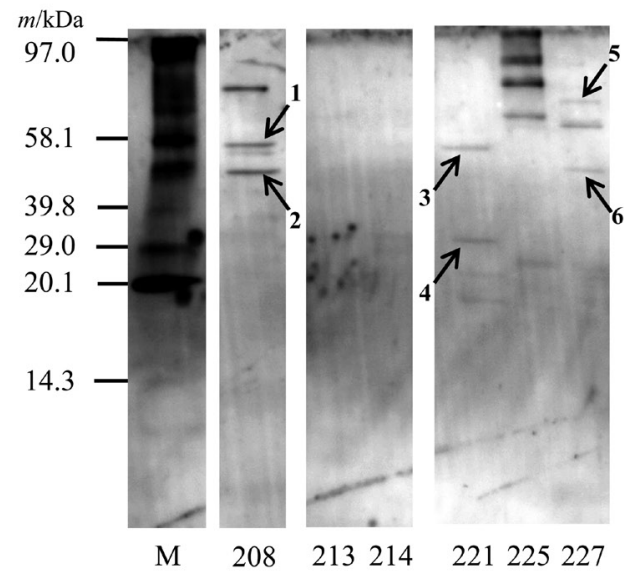

B

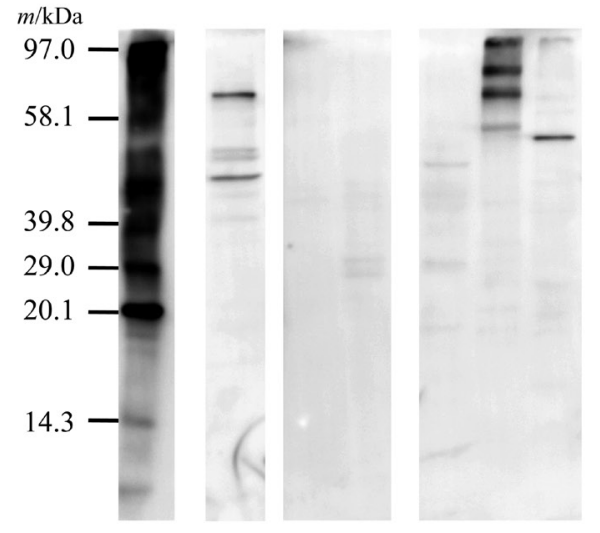

C

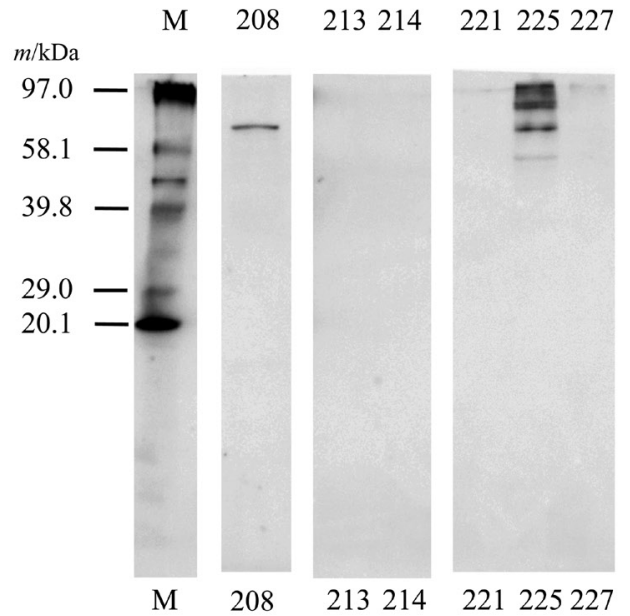

Fig. 3. Detection of adhesins in PBS extracts by a receptor overlay (RO) analysis.

After SDS-PAGE using $1 \mathrm{mg} / \mathrm{ml}$ PBS extracts, proteins were electrophoretically transferred to a PVDF membrane. The membrane was blocked with 5\% skim milk. After washing, the membrane was soaked in TBS-T containing the biotinylated PIM (A), BSA (control protein) (B), or only TBS-T buffer (negative control) (C) overnight. After washing, protein bands were visualized using ExtrAvidin Alkaline Phosphatase Conjugate and ECF substrate with a luminescent image analyzer (excitation, $440 \mathrm{~nm}$; emission, $560 \mathrm{~nm}$ ). M: biotinylated molecular weight marker. The numbers (shows arrows) indicate proteins that were identified (Table 2).
MYU 208, MYU 213, MYU 225, and MYU 227 were significantly lower than that of the positive control $(5.9-8.3 \% ; \mathrm{p}<0.01)$.

\section{Comprehensive analysis of adhesins in PBS extracts from $L A B$}

Figure 3 summarizes the results of the $\mathrm{RO}$ analysis for selected LAB strains. A band at up to $58 \mathrm{kDa}$ (No. 1, Fig. 3 and Table 2) was more clear than that of BSA, a control protein. A ca. $48-\mathrm{kDa}$ band (No. 2, Fig. 3 and Table 2) and a weak ca. $40-\mathrm{kDa}$ band bound to PIM as well as BSA in MYU 208 but did not bind to the buffer control. No clear bands were detected in MYU 213 and MYU 214. In MYU 221, ca. 56-kDa (No. 3, Fig. 3 and Table 2) and ca. 31-kDa (No. 4, Fig. 3 and Table 2) bands were detected more clearly in PIM than in BSA and the buffer control. Four high-molecular-weight bands in MYU 225 were detected in PIM, BSA, and the buffer control, indicating nonspecific binding. In MYU 227, three bands were detected; the bands at ca. $72 \mathrm{kDa}$ (No. 5, Fig. 3 and Table 2) and ca. $48 \mathrm{kDa}$ (No. 6, Fig. 3 and Table 2) were mucin specific, while the ca. $64-\mathrm{kDa}$ band was nonspecifc.

\section{Identification of the adhesins of $L A B$}

The mucin-binding proteins were identified using a homology search of $\mathrm{N}$-terminal amino acid sequences, and the results are summarized in Table 2 . Twenty amino acid residues were determined in all samples. Aca. 58-kDa band (No. 1, Fig. 3 and Table 2) in MYU 208 was determined to be $\mathrm{NH}_{2}-(\mathrm{M}) A K D I K F S E D A R S K M Q A G V D Q$. This protein was identified as GroEL based on homology comparisons of the $\mathrm{N}$-terminal amino acid sequence in the databases. Two proteins at ca. $48 \mathrm{kDa}$ (No. 2, Fig. 3 and Table 2) in MYU 208 were determined to be $\mathrm{NH}_{2}-(\mathrm{M})$ SAITDIYAREVLDSRGNPTV and $\mathrm{NH}_{2}-(\mathrm{M})$ AKETYERTKPHVNIGTIGHV. These proteins were identified as enolase and EF-Tu, respectively. In MYU 221, three proteins were observed at ca. $56 \mathrm{kDa}$ (No. 3, Fig. 3 and Table 2) and ca. $31 \mathrm{kDa}$ (No. 4, Fig. 3 and Table 2). The ca. 56-kDa band was determined to be $\mathrm{NH}_{2}$-(M)VQIDNEDLKQVRSEFLDTAK, $\mathrm{NH}_{2}$-MLKSVIENVHALEIFDSRGN, and $\mathrm{NH}_{2}-(\mathrm{M})$ SENEKFEQNAYAPMKGIKVI; the ca. 31-kDa band was determinedtobe $\mathrm{NH}_{2}$-(M)AKLVLIRHGQSEANLTNQFV, $\mathrm{NH}_{2}$-(M)SRTPIIAGNWKLHMNPEQTV, and $\mathrm{NH}_{2-}$ MIYTVTVNPALDYVMQLEKV. These proteins were identified as peptidase $\mathrm{C} 1$ (PepC), enolase, and formyl-CoA transferase (FRC), respectively, for the ca. 56-kDa protein and phosphoglyceromutase (PGM), triosephosphate isomerase (TPI), and phosphofructokinase (PFK), 


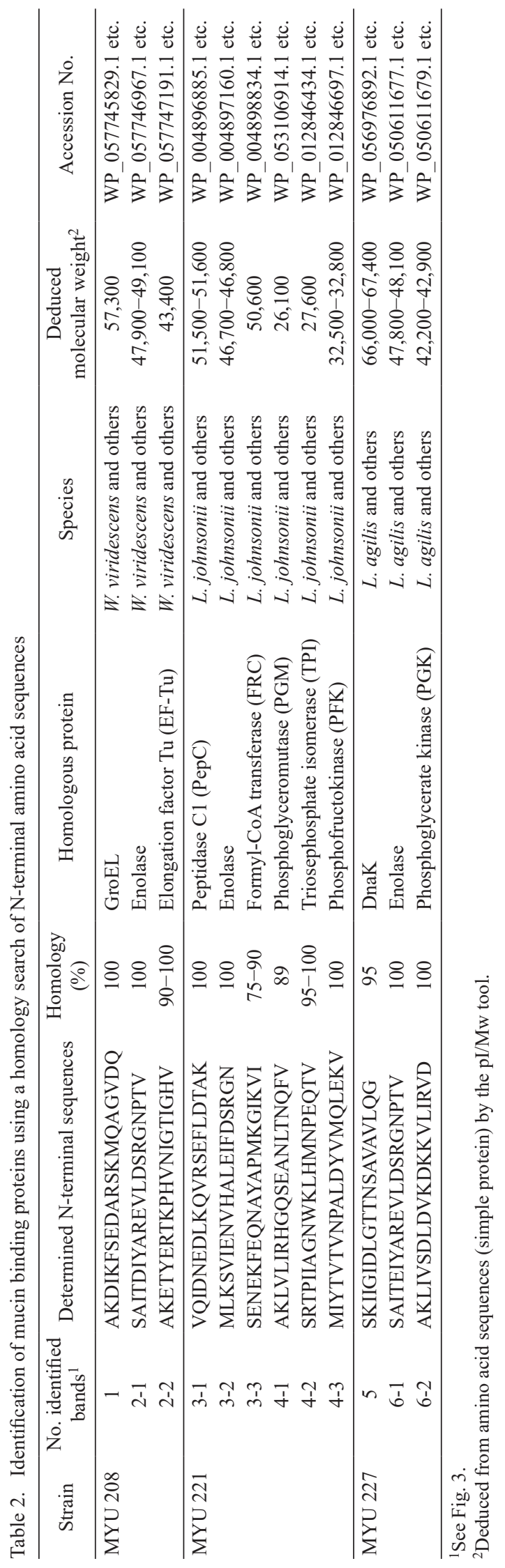


respectively, for the ca. 31-kDa protein. In MYU 227, a ca. 72-kDa band (No. 5, Fig. 3 and Table 2) was determined to be $\mathrm{NH}_{2}$-(M)SKIIGIDLGTTNSAVAVLQG. This protein was identified as DnaK. Two proteins were at ca. $48 \mathrm{kDa}$ (No. 6, Fig. 3 and Table 2) in MYU 227 and were determined to be $\mathrm{NH}_{2}-(\mathrm{M}) A K L I V S D L D V K D K K V L I R V D$ and $\mathrm{NH}_{2}-$ (M)SAITEIYAREVLDSRGNPTV. These proteins were identified as enolase and phosphoglycerate kinase (PGK), respectively.

\section{DISCUSSION}

Adhesion to the intestinal mucosa is very important for LAB to function effectively as probiotics. There are two types of adhesins on the cell surface, membraneassociated proteins, such as the S-layer protein $[12,13]$, and the moonlighting proteins bound by ionic bonds. In this study, we focused on moonlighting proteins that can be easily extracted using PBS. We performed a comprehensive analysis of the adhesins in PBS extracts from $\mathrm{LAB}$.

Using three different culture agars, different species were isolated. When using MRS and BL agars, species other than LAB were detected. These differences may be explained by differences in $\mathrm{pH}$. In previous studies, the selectivity of culture agar for $\mathrm{LAB}$ was shown to be higher at lower $\mathrm{pH}$ values $[40,41]$. However, it is necessary to select the culture agar in accordance with the intended use because an excessively low $\mathrm{pH}$ may obstruct even the growth of lactobacilli [42-45].

Using SDS-PAGE, various band numbers and banding patterns were observed for PBS extracts from the LAB (Fig. 1). Some strains had only a few or no proteins in PBS extracts. In our previous study, GAPDH enzymatic activity was measured in the PBS extracts of 30 lactobacilli isolated from human intestinal tissues and was detected in 21 out of 30 samples from 12-hr cultures and in all samples at $18 \mathrm{hr}$ [34]. This suggests that in moonlighting proteins, such as GAPDH, accumulation is growth-time dependent. Saad et al. [46] reported that the GAPDH concentration on cell walls is growth-time dependent in L. plantarum 299v. This accumulation of GAPDH on the cell surface is related to cell injury. Similar observations were reported by Kainulainen et al. [47] for four moonlighting proteins, i.e., glutamine synthase (GS), glucose-6-phosphate isomerase (GPI), enolase, and GAPDH, from Lactobacillus crispatus ST1. However, it is not clear how moonlighting proteins are secreted onto the bacterial cell surface. Further investigations are needed to clarify their secretion mechanisms.

In the test of adhesion of selected LAB to PIM, MYU
214 showed high adhesion, but no adhesin was detected in the RO analysis for MYU 214 or MYU 213. This suggests that other membrane-associated proteins, such as S-layer proteins and/or extracellular polysaccharides (EPS), may function as adhesins.

In the comprehensive analysis of adhesins in PBS extracts using RO analysis, some moonlighting adhesins were detected (Fig. 3). In MYU 208, the molecular chaperone GroEL was identified as an adhesin (No. 1, Fig. 3 and Table 2). Bergonzelli et al. [48] reported that the GroEL of Lactobacillus johnsonii La1 (NCC 533) binds to mucin and HT29 cells in a pH-dependent manner and stimulates interleukin- 8 secretion in macrophages and HT29 cells in a CD14-dependent manner. Another molecular chaperone, DnaK, was identified in MYU 227 (No. 5, Fig. 3 and Table 2). Katakura et al. [26] reported that many moonlighting proteins show affinity to invertase, a hyperglycosylated mannoprotein from Saccharomyces cerevisiae, and are found in Lactococcus lactis subsp. lactis IL1403. Of the 16 spots of affinitypurified cell wall proteins detected using two-dimensional electrophoresis, 15 were identified as cytosolic proteins, including the molecular chaperones DnaK, GroEL, and GroE, and enzymes in the central metabolic pathway, such as GAPDH, pyruvate kinase (PK), and PFK. These results suggest that DnaK has two independent binding sites, one that is specific to LAB and another that is specific to yeast agglutination.

The ca. $48-\mathrm{kDa}$ band (No. 2, Fig. 3 and Table 2) in MYU 208 was identified as enolase and/or EF-Tu. Based on the molecular weight, enolase may be an adhesin, and EF-Tu may be as well. Both may be detected in a mixed state, as they have been reported as adhesins [29, $31,48]$. Similar results were observed for the ca. $48-\mathrm{kDa}$ band in MYU 227 (No. 6, Fig. 3 and Table 2), which was associated with enolase and/or PGK. In this case, the molecular weight suggests that enolase may also be an adhesin. Sánchez et al. [49] reported that GAPDH and PGK are expressed on the cell surface of Lactobacillus rhamnosus GG but that none of the proteins bind to mucin or fibronectin. A weak band at ca. $40 \mathrm{kDa}$ was also detected in MYU 208. This most likely corresponded to GAPDH, as many reports have shown that $40-\mathrm{kDa}$ GAPDH binds to various substances in the intestinal tract, such as mucin, extracellular matrix, and intestinal epithelial cells $[25,28,50,51]$. However, the protein could not be clearly identified because the band was very weak and showed nonspecific binding.

Three different proteins were identified in the ca. 56-kDa band (No. 3, Fig. 3 and Table 2) and the ca. 31kDa band (No. 4, Fig. 3 and Table 2) in MYU 221. The 
ca. 56-kDa protein contained PepC, enolase, and FRC. Donkor et al. [52] reported amino peptidase activity in both extracellular and intracellular extracts from some Lactobacillus helveticus strains, suggesting the presence of general amino peptidases, such as PepC and PepN. Shihata and Shah [53] found similar aminopeptidase activity in many strains of LAB and bifidobacteria at both extracellular and intracellular levels. FRC catalases transfer coenzyme A $(\mathrm{CoA})$ from formate to oxalate in the first step of oxalate degradation and has a CoA binding site [54]. To our knowledge, however, no study has demonstrated that PepC and FRC bind to mucin. Additional experiments using recombinant proteins are needed to demonstrate whether these proteins are adhesins.

PGM, TPI, and/or PFK were identified as candidate adhesins in the ca. 31-kDa band from MYU 221 (No. 4, Fig. 3 and Table 2). PGM is a plasminogen-binding protein in Bifidobacterium lactis BI07, as are DnaK, GS, enolase, and bile salt hydrolase [55]. TPI is an adhesin that binds to Caco-2 cells, in addition to GAPDH and $\mathrm{EF}-\mathrm{Tu}$ in L. plantarum 423 [56]. PFK is an adhesin in L. lactis subsp. lactis IL1403; it binds to mannoprotein [26]. These three proteins may not be separable by SDSPAGE. They were detected as a single band owing to their highly similar molecular weights. At least one of the proteins is an adhesin that binds to PIM, but additional experiments are needed to clarify whether all three proteins are adhesins.

In this study, $18 \mathrm{LAB}$ were isolated from PIM, and various moonlighting adhesins were detected in the PBS extracts of the LAB based on an RO analysis. These proteins in the PBS extracts, which included such things as molecular chaperones and glycolytic enzymes, may play important roles as adhesins. Recently, many studies have demonstrated that moonlighting proteins bind to various substances, such as mucin [28], A and B blood type antigens [33], sulfated carbohydrates [31], intestinal epithelial cells [56], fibronectin and collagen [50], actin [57], and plasminogen [29]. These reports suggest the importance of moonlighting proteins on the cell surfaces of LAB as adhesins. The binding mechanisms are not clear, but some moonlighting proteins may bind to PIM via mechanisms other than ionic bonds because the moonlighting proteins detected in this study remained after washing with PBS-T, which contained many salts and Tween 20. Previously, we reported that GAPDH may be an $N$-acetylgalactosamine and a galactose recognition lectin-like protein and that the trisaccharide structure is important for binding to blood group antigens [33]. Moreover, the surface GAPDH of Streptococcus pyogenes ATCC 700294 binds to the $\mathrm{N}$-terminal domain (D1) of uPAR (urokinase plasminogen activator receptor)/CD87 as its receptor on human pharyngeal cells, while uPAR-D1 more specifically binds to the C-terminal alpha-helix and two immediate flanking regions of the S-loop of the GAPDH molecule [58]. Streptococcal GAPDH shows multiple binding activities to plasmin(ogen) [59,60], fibronectin, lysozyme, myosin, and actin [61]. It is difficult to explain these observations of multibinding by ionic bonds alone. Furthermore, the multiple functionalities of moonlighting proteins, other than their functions as adhesins, are enhanced with tPA- and uPA-mediated plasminogen activation [62], protecting LAB from environmental stress [55, 63-65] and stimulating the immune response of the host [48, $51,66]$. We can use these moonlighting proteins as functional markers to select useful probiotic LAB strains in the future. Additional studies are needed to clarify the binding mechanisms and the various functions of moonlighting proteins, including adhesins.

\section{ACKNOWLEDGEMENTS}

The authors gratefully thank Ms. Tsugumi Shiokawa and Dr. Hiroko Tada at the Division of Instrumental Analysis, Department of Instrumental Analysis \& Cryogenics, Advanced Science Research Center, Okayama University, for the amino acid sequence analyses. This study was partially supported by a Grant-in-Aid for Study on Milk Nutrition (2010) from the Japan Dairy Association (J-milk).

\section{REFERENCES}

1. Savaiano DA, Kotz C. 1989. Recent advances in the management of lactose intolerance. ASDC J Dent Child 56: 228-233. [Medline]

2. Danielson AD, Peo ER Jr, Shahani KM, Lewis AJ, Whalen PJ, Amer MA. 1989. Anticholesteremic property of Lactobacillus acidophilus yogurt fed to mature boars. J Anim Sci 67: 966-974. [Medline] [CrossRef]

3. Perdigón G, Maldonado Galdeano C, Valdez JC, Medici M. 2002. Interaction of lactic acid bacteria with the gut immune system. Eur J Clin Nutr 56 Suppl 4: S21-S26. [Medline] [CrossRef]

4. Lim BK, Mahendran R, Lee YK, Bay BH. 2002. Chemopreventive effect of Lactobacillus rhamnosus on growth of a subcutaneously implanted bladder cancer cell line in the mouse. Jpn J Cancer Res 93: 36-41. [Medline] [CrossRef]

5. Varma P, Dinesh KR, Menon KK, Biswas R. 2010. Lactobacillus fermentum isolated from human colonic mucosal biopsy inhibits the growth and adhesion of enteric and foodborne pathogens. J Food Sci 75: M546-M551. [Medline] [CrossRef] 
6. Mack DR, Michail S, Wei S, McDougall L, Hollingsworth MA. 1999. Probiotics inhibit enteropathogenic $E$. coli adherence in vitro by inducing intestinal mucin gene expression. Am J Physiol 276: G941-G950. [Medline]

7. Chen X, Xu J, Shuai J, Chen J, Zhang Z, Fang W. 2007. The S-layer proteins of Lactobacillus crispatus strain ZJ001 is responsible for competitive exclusion against Escherichia coli O157:H7 and Salmonella typhimurium. Int J Food Microbiol 115: 307-312. [Medline] [CrossRef]

8. Ahrné S, Nobaek S, Jeppsson B, Adlerberth I, Wold AE, Molin G. 1998. The normal Lactobacillus flora of healthy human rectal and oral mucosa. J Appl Microbiol 85: 88-94. [Medline] [CrossRef]

9. Dunne C, Murphy L, Flynn S, O’Mahony L, O'Halloran S, Feeney M, Morrissey D, Thornton G, Fitzgerald G, Daly C, Kiely B, Quigley EM, O’Sullivan GC, Shanahan F, Collins JK. 1999. Probiotics: from myth to reality. Demonstration of functionality in animal models of disease and in human clinical trials. Antonie van Leeuwenhoek 76: 279-292. [Medline] [CrossRef]

10. Song YL, Kato N, Matsumiya Y, Liu CX, Kato H, Watanabe K. 1999. Identification of and hydrogen peroxide production by fecal and vaginal lactobacilli isolated from Japanese women and newborn infants. J Clin Microbiol 37: 3062-3064. [Medline]

11. Heilig HG, Zoetendal EG, Vaughan EE, Marteau P, Akkermans AD, de Vos WM. 2002. Molecular diversity of Lactobacillus spp. and other lactic acid bacteria in the human intestine as determined by specific amplification of $16 \mathrm{~S}$ ribosomal DNA. Appl Environ Microbiol 68: 114-123. [Medline] [CrossRef]

12. Hynönen U, Westerlund-Wikström B, Palva A, Korhonen TK. 2002. Identification by flagellum display of an epithelial cell- and fibronectin-binding function in the SlpA surface protein of Lactobacillus brevis. J Bacteriol 184: 3360-3367. [Medline] [CrossRef]

13. Uchida H, Kinoshita H, Kawai Y, Kitazawa H, Miura K, Shiiba K, Horii A, Kimura K, Taketomo N, Oda M, Yajima T, Saito T. 2006. Lactobacilli binding human A-antigen expressed in intestinal mucosa. Res Microbiol 157: 659-665. [Medline] [CrossRef]

14. Altermann E, Buck LB, Cano R, Klaenhammer TR. 2004. Identification and phenotypic characterization of the cell-division protein CdpA. Gene 342: 189-197. [Medline] [CrossRef]

15. Roos S, Jonsson H. 2002. A high-molecular-mass cell-surface protein from Lactobacillus reuteri 1063 adheres to mucus components. Microbiology 148: 433-442. [Medline] [CrossRef]

16. Buck BL, Altermann E, Svingerud T, Klaenhammer TR. 2005. Functional analysis of putative adhesion factors in Lactobacillus acidophilus NCFM. Appl Environ Microbiol 71: 8344-8351. [Medline] [CrossRef]

17. Sillanpää J, Martínez B, Antikainen J, Toba T, Kalkkinen
N, Tankka S, Lounatmaa K, Keränen J, Höök M, Westerlund-Wikström B, Pouwels PH, Korhonen TK. 2000. Characterization of the collagen-binding S-layer protein CbsA of Lactobacillus crispatus. J Bacteriol 182: 6440-6450. [Medline] [CrossRef]

18. Pretzer G, Snel J, Molenaar D, Wiersma A, Bron PA, Lambert J, de Vos WM, van der Meer R, Smits MA, Kleerebezem M. 2005. Biodiversity-based identification and functional characterization of the mannose-specific adhesin of Lactobacillus plantarum. J Bacteriol 187: 6128-6136. [Medline] [CrossRef]

19. Roos S, Aleljung P, Robert N, Lee B, Wadström T, Lindberg M, Jonsson H. 1996. A collagen binding protein from Lactobacillus reuteri is part of an ABC transporter system? FEMS Microbiol Lett 144: 33-38. [Medline] [CrossRef]

20. Watanabe M, Kinoshita H, Nitta M, Yukishita R, Kawai Y, Kimura K, Taketomo N, Yamazaki Y, Tateno Y, Miura K, Horii A, Kitazawa H, Saito T. 2010. Identification of a new adhesin-like protein from Lactobacillus mucosae ME-340 with specific affinity to the human blood group A and B antigens. J Appl Microbiol 109: 927-935. [Medline] [CrossRef]

21. Rojas M, Ascencio F, Conway PL. 2002. Purification and characterization of a surface protein from Lactobacillus fermentum 104R that binds to porcine small intestinal mucus and gastric mucin. Appl Environ Microbiol 68: 2330-2336. [Medline] [CrossRef]

22. van Pijkeren JP, Canchaya C, Ryan KA, Li Y, Claesson MJ, Sheil B, Steidler L, O’Mahony L, Fitzgerald GF, van Sinderen D, O'Toole PW. 2006. Comparative and functional analysis of sortase-dependent proteins in the predicted secretome of Lactobacillus salivarius UCC118. Appl Environ Microbiol 72: 4143-4153. [Medline] [CrossRef]

23. Greene JD, Klaenhammer TR. 1994. Factors involved in adherence of lactobacilli to human Caco-2 cells. Appl Environ Microbiol 60: 4487-4494. [Medline]

24. Sherman LA, Savage DC. 1986. Lipoteichoic acids in Lactobacillus strains that colonize the mouse gastric epithelium. Appl Environ Microbiol 52: 302-304. [Medline]

25. Glenting J, Beck HC, Vrang A, Riemann H, Ravn P, Hansen AM, Antonsson M, Ahrné S, Israelsen H, Madsen S. 2013. Anchorless surface associated glycolytic enzymes from Lactobacillus plantarum $299 \mathrm{v}$ bind to epithelial cells and extracellular matrix proteins. Microbiol Res 168: 245-253. [Medline] [CrossRef]

26. Katakura Y, Sano R, Hashimoto T, Ninomiya $K$, Shioya S. 2010. Lactic acid bacteria display on the cell surface cytosolic proteins that recognize yeast mannan. Appl Microbiol Biotechnol 86: 319-326. [Medline] [CrossRef]

27. Kainulainen V, Korhonen TK. 2014. Dancing to another tune-adhesive moonlighting proteins in 
bacteria. Biology (Basel) 3: 178-204. [Medline]

28. Kinoshita H, Uchida H, Kawai Y, Kawasaki T, Wakahara N, Matsuo H, Watanabe M, Kitazawa H, Ohnuma S, Miura K, Horii A, Saito T. 2008. Cell surface Lactobacillus plantarum LA 318 glyceraldehyde-3phosphate dehydrogenase (GAPDH) adheres to human colonic mucin. J Appl Microbiol 104: 1667-1674. [Medline] [CrossRef]

29. Hurmalainen V, Edelman S, Antikainen J, Baumann M, Lähteenmäki K, Korhonen TK. 2007. Extracellular proteins of Lactobacillus crispatus enhance activation of human plasminogen. Microbiology 153: 1112-1122. [Medline] [CrossRef]

30. Antikainen J, Kuparinen V, Lähteenmäki K, Korhonen TK. 2007. pH-dependent association of enolase and glyceraldehyde-3-phosphate dehydrogenase of Lactobacillus crispatus with the cell wall and lipoteichoic acids. J Bacteriol 189: 4539-4543. [Medline] [CrossRef]

31. Nishiyama K, Ochiai A, Tsubokawa D, Ishihara K, Yamamoto Y, Mukai T. 2013. Identification and characterization of sulfated carbohydrate-binding protein from Lactobacillus reuteri. PLoS One 8: e83703. [Medline] [CrossRef]

32. Kinoshita H, Uchida H, Kawai Y, Kitazawa H, Miura K, Shiiba K, Horii A, Saito T. 2007. Quantitative evaluation of adhesion of lactobacilli isolated from human intestinal tissues to human colonic mucin using surface plasmon resonance (BIACORE assay). J Appl Microbiol 102: 116-123. [Medline] [CrossRef]

33. Kinoshita H, Wakahara N, Watanabe M, Kawasaki T, Matsuo H, Kawai Y, Kitazawa H, Ohnuma S, Miura K, Horii A, Saito T. 2008. Cell surface glyceraldehyde-3phosphate dehydrogenase (GAPDH) of Lactobacillus plantarum LA 318 recognizes human $\mathrm{A}$ and $\mathrm{B}$ blood group antigens. Res Microbiol 159: 685-691. [Medline] [CrossRef]

34. Kinoshita H, Sohma Y, Ohtake F, Ishida M, Kawai Y, Kitazawa H, Saito T, Kimura K. 2013. Biosorption of heavy metals by lactic acid bacteria and identification of mercury binding protein. Res Microbiol 164: 701709. [Medline] [CrossRef]

35. Reed DL, Hafner MS. 2002. Phylogenetic analysis of bacterial communities associated with ectoparasitic chewing lice of pocket gophers: a culture-independent approach. Microb Ecol 44: 78-93. [Medline] [CrossRef]

36. Dubois M, Gilles K, Hamilton JK, Rebers PA, Smith F. 1956. Colorimetric method for determination of sugars and related substances. Anal Chem 28: 350-356. [CrossRef]

37. Laemmli UK. 1970. Cleavage of structural proteins during the assembly of the head of bacteriophage T4. Nature 227: 680-685. [Medline] [CrossRef]

38. Ilver D, Arnqvist A, Ogren J, Frick IM, Kersulyte D, Incecik ET, Berg DE, Covacci A, Engstrand L, Borén T.
1998. Helicobacter pylori adhesin binding fucosylated histo-blood group antigens revealed by retagging. Science 279: 373-377. [Medline] [CrossRef]

39. Edman P. 1950. A method for the determination of amino acid sequence in peptides. Acta Chem Scand 4: 283-293. [CrossRef]

40. Hartemink R, Domenech VR, Rombouts FM. 1997. LAMVAB - a new selective medium for the isolation of lactobacilli from faeces. J Microbiol Methods 29: 77-84. [CrossRef]

41. Kinoshita H, Imoto S, Suda Y, Ishida M. 2011. Comparison of selectivity of MRS agar and modifed LBS agar for isolation of lactobacilli. Milk Sci 60: 171-176.

42. Kõll P, Mändar R, Marcotte H, Leibur E, Mikelsaar M, Hammarström L. 2008. Characterization of oral lactobacilli as potential probiotics for oral health. Oral Microbiol Immunol 23: 139-147. [Medline] [CrossRef]

43. Fernández MF, Boris S, Barbés C. 2003. Probiotic properties of human lactobacilli strains to be used in the gastrointestinal tract. J Appl Microbiol 94: 449455. [Medline] [CrossRef]

44. Dunne C, O’Mahony L, Murphy L, Thornton G, Morrissey D, O'Halloran S, Feeney M, Flynn S, Fitzgerald G, Daly C, Kiely B, O’Sullivan GC, Shanahan F, Collins JK. 2001. In vitro selection criteria for probiotic bacteria of human origin: correlation with in vivo findings. Am J Clin Nutr 73 Suppl: 386S-392S. [Medline]

45. Delgado S, O’Sullivan E, Fitzgerald G, Mayo B. 2007. Subtractive screening for probiotic properties of Lactobacillus species from the human gastrointestinal tract in the search for new probiotics. J Food Sci 72: M310-M315. [Medline] [CrossRef]

46. Saad N, Urdaci M, Vignoles C, Chaignepain S, Tallon R, Schmitter JM, Bressollier P. 2009. Lactobacillus plantarum 299v surface-bound GAPDH: a new insight into enzyme cell walls location. J Microbiol Biotechnol 19: 1635-1643. [Medline] [CrossRef]

47. Kainulainen V, Loimaranta V, Pekkala A, Edelman S, Antikainen J, Kylväjä R, Laaksonen M, Laakkonen L, Finne J, Korhonen TK. 2012. Glutamine synthetase and glucose-6-phosphate isomerase are adhesive moonlighting proteins of Lactobacillus crispatus released by epithelial cathelicidin LL-37. J Bacteriol 194: 2509-2519. [Medline] [CrossRef]

48. Bergonzelli GE, Granato D, Pridmore RD, Marvin-Guy LF, Donnicola D, Corthésy-Theulaz IE. 2006. GroEL of Lactobacillus johnsonii La1 (NCC 533) is cell surface associated: potential role in interactions with the host and the gastric pathogen Helicobacter pylori. Infect Immun 74: 425-434. [Medline] [CrossRef]

49. Sánchez B, Schmitter JM, Urdaci MC. 2009. Identification of novel proteins secreted by Lactobacillus rhamnosus GG grown in de Mann- 
Rogosa-Sharpe broth. Lett Appl Microbiol 48: 618622. [Medline] [CrossRef]

50. Muñoz-Provencio D, Pérez-Martínez G, Monedero V. 2011. Identification of surface proteins from Lactobacillus casei BL23 able to bind fibronectin and collagen. Probiotics Antimicrob Proteins 3: 15-20. [Medline] [CrossRef]

51. Martín R, Sánchez B, Urdaci MC, Langella P, Suárez JE, Bermúdez-Humarán LG. 2015. Effect of iron on the probiotic properties of the vaginal isolate Lactobacillus jensenii CECT 4306. Microbiology 161: 708-718. [Medline] [CrossRef]

52. Donkor ON, Henriksson A, Vasiljevic T, Shah NP. 2007. Proteolytic activity of dairy lactic acid bacteria and probiotics as determinant of growth and in vitro angiotensin-converting enzyme inhibitory activity in fermented milk. Lait 87: 21-38. [CrossRef]

53. Shihata A, Shah NP. 2000. Proteolytic profiles of yogurt and probiotic bacteria. Int Dairy J 10: 401-408. [CrossRef]

54. Ricagno S, Jonsson S, Richards N, Lindqvist Y. 2003. Formyl-CoA transferase encloses the CoA binding site at the interface of an interlocked dimer. EMBO J 22: 3210-3219. [Medline] [CrossRef]

55. Candela M, Centanni M, Fiori J, Biagi E, Turroni S, Orrico C, Bergmann S, Hammerschmidt S, Brigidi P. 2010. DnaK from Bifidobacterium animalis subsp. lactis is a surface-exposed human plasminogen receptor upregulated in response to bile salts. Microbiology 156: 1609-1618. [Medline] [CrossRef]

56. Ramiah K, van Reenen CA, Dicks LM. 2008. Surfacebound proteins of Lactobacillus plantarum 423 that contribute to adhesion of Caco-2 cells and their role in competitive exclusion and displacement of Clostridium sporogenes and Enterococcus faecalis. Res Microbiol 159: 470-475. [Medline] [CrossRef]

57. Peng Z, Krey V, Wei H, Tan Q, Vogelmann R, Ehrmann MA, Vogel RF. 2014. Impact of actin on adhesion and translocation of Enterococcus faecalis. Arch Microbiol 196: 109-117. [Medline] [CrossRef]

58. Antikainen J, Kuparinen V, Lähteenmäki K, Korhonen TK. 2007. Enolases from Gram-positive bacterial pathogens and commensal lactobacilli share functional similarity in virulence-associated traits. FEMS
Immunol Med Microbiol 51: 526-534. [Medline] [CrossRef]

59. Jin H, Song YP, Boel G, Kochar J, Pancholi V. 2005. Group A streptococcal surface GAPDH, SDH, recognizes $\mathrm{uPAR} / \mathrm{CD} 87$ as its receptor on the human pharyngeal cell and mediates bacterial adherence to host cells. J Mol Biol 350: 27-41. [Medline] [CrossRef]

60. D'Costa SS, Boyle MD. 2000. Interaction of group A streptococci with human plasmin(ogen) under physiological conditions. Methods 21: 165-177. [Medline] [CrossRef]

61. Winram SB, Lottenberg R. 1996. The plasmin-binding protein Plr of group A streptococci is identified as glyceraldehyde-3-phosphate dehydrogenase. Microbiology 142: 2311-2320. [Medline] [CrossRef]

62. Pancholi V, Fischetti VA. 1992. A major surface protein on group A streptococci is a glyceraldehyde3-phosphate-dehydrogenase with multiple binding activity. J Exp Med 176: 415-426. [Medline] [CrossRef]

63. Prasad J, McJarrow P, Gopal P. 2003. Heat and osmotic stress responses of probiotic Lactobacillus rhamnosus HN001 (DR20) in relation to viability after drying. Appl Environ Microbiol 69: 917-925. [Medline] [CrossRef]

64. Sánchez B, Champomier-Vergès MC, Stuer-Lauridsen B, Ruas-Madiedo P, Anglade P, Baraige F, de los Reyes-Gavilán CG, Johansen E, Zagorec M, Margolles A. 2007. Adaptation and response of Bifidobacterium animalis subsp. lactis to bile: a proteomic and physiological approach. Appl Environ Microbiol 73: 6757-6767. [Medline] [CrossRef]

65. Carreté R, Reguant C, Bordons A, Constantí M. 2005. Relationship between a stress membrane protein of Oenococcus oeni and glyceraldehyde-3-phosphate dehydrogenases. Appl Biochem Biotechnol 127: 43-51. [Medline] [CrossRef]

66. Granato D, Bergonzelli GE, Pridmore RD, Marvin L, Rouvet M, Corthésy-Theulaz IE. 2004. Cell surface-associated elongation factor Tu mediates the attachment of Lactobacillus johnsonii NCC533 (La1) to human intestinal cells and mucins. Infect Immun 72: 2160-2169. [Medline] [CrossRef] 